\title{
Comparative Pharmacognostic, Phytochemical and Biological evaluation between five Chlorophytum species
}

\author{
Sharada Laxman Deore ${ }^{* 1}$, Neha Brijmohan Jajoo', Kailaspati Prabhakar Chittam², Tushar Atmaram Deshmukh³ \\ 'Department of Pharmacognosy and Phytochemistry, Government College of Pharmacy, Amravati, Maharashtra, India. \\ 2Department of Pharmacognosy, A. R. A. College of Pharmacy, Deopur road, Nagaon, Dhule Maharashtra, India. \\ 'Department of Pharmacognosy, Tapi Valley Education Society's Hon'ble, Loksevak Madhukarrao Chaudhari College of Pharmacy, Faizpur, Maharashtra, India.
}

\begin{abstract}
Objective: To establish comparative pharmacognostic, phytochemical and biological evaluation parameters between five Chlorophytum species i.e. Chlorophytum borivilianum Santapau and Fernades, Chlorophytum comosum (Thunb.) Jacq., Chlorophytum tuberosum Br., Chlorophytum laxum R. $\mathrm{Br}$. and Chlorophytum arundinaceum Baker, of very popular Ayurvedic plant Safed Musali. Materials and methods: Comparative evaluations of Macro and microscopical, physico-chemical parameters of tubers of all five species were investigated and preliminary phytochemical analysis, estimation of major phytochemicals and TLC profiles were also carried out for qualitative phytochemical evaluation. In-vitro antioxidant and anticancer activity was carried out for extract of tubers of all five species. Results: Macro, micro, powder microscopical parameters of tubers of five species were examined and recorded the result. Tubers of all the five species are distinct in their morphology as well as anatomical characters. Physicochemical characters (Ash values, Loss on drying (LOD), swelling index and foaming index) as well as total saponin content shows great variability among five species. Results of In-vitro antioxidant by DPPH method shows difference in antioxidant potential between tubers of all five species. Extract of tubers of all five species do not show any type of In-vitro anticancer activity by SRB method against HL 60 leukemia cell line. Conclusion: All of the evaluated parameters are very good pharmacognostic standards for future comparative identification and authentication of specific species because all five species shows morphological, anatomical, chemical differences as well as varies in antioxidant potential.
\end{abstract}

Key words: Arundinaceum, Borivilianum, Chlorophytum Comosum, DPPH, HL-60, Laxum, SRB, Tuberosum.

\section{SUMMARY}

- Safed musli is very popular Ayurvedic drug and ingredient of many herbal formulations.

- There are almost 215 species that have been reported in the genus Chlorophytum.

- Unfortunately, most of these species are indistinguishable.
- Incorrect identification affects quality and efficacy of medicinal products containing this plant.

- Evaluated parameters in this work are very good pharmacognostic standards for future comparative identification and authentication of specific species.

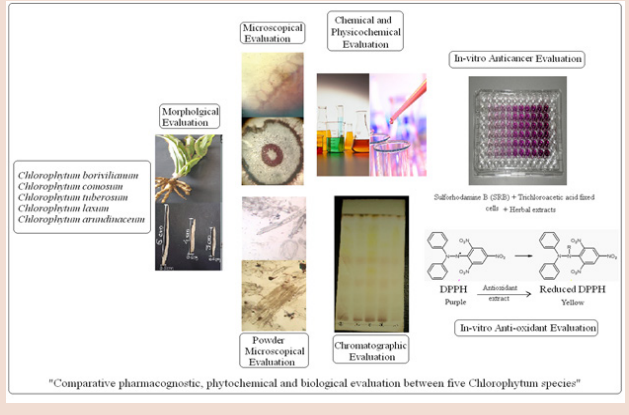

PICTORIAL ABSTRACT

Abbreviations used: LOD: Loss on drying, DPPH: 2,2-diphenyl-1-picrylhydrazyl, SRB: Sulforhodamine B, CB: Chlorophytum borivilianum, CC: Chlorophytum comosum, CT: Chlorophytum tuberosum, CL: Chlorophytum laxum, CA: Chlorophytum arundinaceum, AE: Aqueous extract, EE: Ethanolic extract, WHO: World Health Organisation, ACTREC: Advanced Center for Treatment, Research and Education in Cancer.

\section{Correspondence:}

Dr. Sharada Laxman Deore, Department of Pharmacognosy and Phytochemistry, Government College of Pharmacy, Amravati, Maharashtra, India.

Email: sharudeore_2@yahoo.com

DOI : 10.5530/pj.2015.5.12

\section{INTRODUCTION}

A number of species belonging to the genus Chlorophytum are noted for their medicinal benefits in Ayurvedic, and Unani system of medicine are popularly known as safed musli. ${ }^{1}$ Traditionally, roots of these species are reputed to possess various pharmacological utilities like immunemodulation, adaptogenic, aphrodisiac and anti-stress properties due to saponins as one of the important phytochemical constituents. Safed musli is one of the ingredients of Chyawanprash, a very popular and useful Ayurvedic rasayana (rejuvenator) formulation. There are almost 215 species that have been reported in the genus Chlorophytum., ${ }^{2,3}$ All are perennial rhizomatous herbs. Rhizomes are often short and inconspicuous while roots are usually thicker or slightly fleshy. The important plants which have so far been explored include C. adescendens, C. borivilianum, C. laxum, C. tuberosum and C. comosum. ${ }^{4}$ Unfortunately, most of these species are indistinguishable morphologically in the field or from photographs as well as from literature and hence chances of incorrect iden- tification are more which surely affects quality and efficacy of medicinal products containing this plant. So we aimed to establish comparative pharmacognostic (macroscopical, histological, powder microscopical, physicochemical and World Health Organisation (WHO) parameters) and phytochemical (preliminary phytochemical evaluation, saponin estimation and TLC profile of extract) diagnostic parameters.

Chlorophytum species are rich in both monodesmosidic saponins (oligosaccharide chain attached at C3 position) and bidesmosidic saponins (an additional sugar moiety at the C26 or C28 positions). ${ }^{5,6}$ Saponins are a group of naturally occurring plant glycosides, characterized by their strong foam forming properties in aqueous solution. The presence of $\mathrm{s}$ ponins has been reported in more than 100 families of plants out of which at least 90 kinds of natural saponins have been found to possess significant anti-cancer properties. There are more than 11 distinguished classes of saponins including dammaranes, tirucallanes, lupanes, hopanes, ole- 
ananes, taraxasteranes, ursanes, cycloartanes, lanostanes, cucurbitanes and steroids. ${ }^{7}$ Due to the great variability of their structures, saponins always display anti-tumorigenic effects through varieties of antitumor

pathways. ${ }^{8}$ In addition, there are a large amount of saponins that still either remain to be trapped or studied in details by the medicinal chemists. Free radicals are major cause of cancer cell development. Saponin, flavonoids and alkaloids are very well known to have immunomodulater, antioxidant and anticancer properties. ${ }^{9}$ So in present thesis it is decided to evaluate saponin fractions of different Chlorophytum species for their probable in vitro antioxidant and in vitro anticancer potential.

\section{MATERIALS AND METHODS}

\section{Material collection, identification and authentication}

The plant materials were collected from in and around Amravati and Akola district (Maharashtra) during the rainy season of year 2012 and 2013 for correct botanical identification. Herbarium specimens were prepared of collected species of Chlorophytum and authenticated from Dr. Prabha Y. Bhogonkar (Director, Government Vidarbha Institute of Science and Humanities, Amravati) and Dr. Arvind S. Dhabe Professor, Department of Botany, Dr. Babasaheb Ambedkar Marathwada University, Aurangabad.

\section{Pharmacognostic evaluation, Macroscopic and Microscopic evaluation}

Macroscopy of tubers was studied by observing the organoleptic characters such as color, size, texture and surface characteristics. Thin hand cut sections were taken from the fresh tubers of all collected species, transferred to a watch glass containing water with the help of brush. Collected species were also subjected to powder microscopy. Thin uniform sections and powder of collected species were mounted on a slide and were treated with different reagents such as Phloroglucinol and hydrochloric acid (to establish lignifications in cells and tissues), Iodine solution (to determine starch grains content), Sudan red Solution (to determine the presence of oil globules). ${ }^{10}$

\section{Physicochemical evaluation}

Tubers of collected species were dried under the shade so as to avoid the decomposition of chemical constituents, powdered in a multi-mill and stored in dry air tied containers for phytochemical screening. Ash values, LOD, swelling index, and foaming index was measured by following the standard pharmacopoeial techniques. Powder materials of collected species were subjected to fluorescence analysis. Qualitative phytochemical tests were carried out by standard methods. Quantitative phytochemical analysis was carried out for estimation of saponin content by gravimetric analysis. ${ }^{11}$

\section{Phytochemical evaluation}

Qualitative phytochemical tests were carried out by standard methods. Quantitative phytochemical analysis was carried out for estimation of saponin content by gravimetric analysis. ${ }^{11}$

\section{Extraction and fractionation}

The root powder of C. borivilianum, C. comosum, C. laxum, C. tuberosum and C. arundinaceum were extracted by microwave assisted extraction in methanol. In microwave extraction, microwave power was $20 \%$, irradiation temperature was $40^{\circ} \mathrm{C}$ and extraction is carried out for 10 min. Methanolic extract of C. borivilianum, C. comosum, C. laxum, C. tuberosum and C. arundinaceum are subjected to thin layer chromatography to confirm the presence of saponin. Saponin of C. borivilianum, C. comosum, C. laxum, C. tuberosum and C. arundinaceum were isolated by precipitation method. Dissolve methanolic extract in methanol, and add diethyl ether dropwise until complete precipitation of saponin is ob- tained. Air dry saponin fraction and store in tightly closed container. ${ }^{12}$

\section{Chromatographic Studies ${ }^{13}$}

TLC of methanolic extracts of all five Chlorophytum species for 2 mobile phases done to evaluate qualitative difference for the presence of saponins in theses selected five species. All chromatographic parameters are given in Table 4.

\section{In vitro antioxidant activity by DPPH method $^{14}$}

$\mathrm{DPPH}$ free radical scavenging method is used for determination of in vitro antioxidant activity. $1 \mathrm{ml}$ different concentration of extract solution and standard (Ascorbic acid) were taken in different vials. To this 5 $\mathrm{ml}$ of methanolic solution of DPPH was added, shaken well \& mixture was incubated at $37^{\circ} \mathrm{C}$ for $20 \mathrm{~min}$. The absorbance was measured against methanol as blank at $516 \mathrm{~nm}$. Absorbance of DPPH was taken as control. Percentage antiradical activity calculated by using following formula;

$\%$ Anti-radical activiity $=\frac{\text { Control Absorbance }- \text { Sample Absorbance }}{\text { Control Absorbance }} \times 100$

\section{In-vitro anticancer screening by SRB assay method}

The anticancer activities of extracts were studied at Advanced Center for Treatment, Research and Education in Cancer (ACTREC), Mumbai. The monolayer cell culture was trypsinized and the cell count was adjusted to $0.5-1.0 \times 105$ cells $/ \mathrm{ml}$ using medium containing $10 \%$ new born sheep serum. To each well of the 96 well microtitre plate, $0.1 \mathrm{ml}$ of the diluted cell suspension (approximately 10,000 cells) was added. After 24 hours, when a partial monolayer was formed, the supernatant was flicked off, washed once and $100 \mu \mathrm{l}$ of different test compound concentrations were added to the cells in microtitre plates. The plates were then incubated at $37^{\circ} \mathrm{C}$ for 72 hours in $5 \% \mathrm{CO}_{2}$ incubator, microscopic examination was carried out, and observations recorded every 24 hours. After 72 hours, $25 \mu \mathrm{l}$ of $50 \%$ trichloroacetic acid was added to the wells gently such that it forms a thin layer over the test compounds to form overall concentration $10 \%$. The plates were incubated at $4{ }^{\circ} \mathrm{C}$ for one hour. The plates were flicked and washed five times with tap water to remove traces of medium, sample and serum, and were then air-dried. The air-dried plates were stained with $100 \mu \mathrm{l}$ sulforhodamine-B (SRB) and kept for 30 minutes at room temperature. The unbound dye was removed by rapidly washing four times with $1 \%$ acetic acid. The plates were then air dried. The air-dried plates were stained with $100 \mu \mathrm{l} \mathrm{SRB}$ and kept for 30 minutes at room temperature. The unbound dye was removed by rapidly washing four times with $1 \%$ acetic acid. The plates were then air dried. $100 \mu \mathrm{l}$ of $10 \mathrm{mM}$ Tris base was then added from wells to solubilize the dye. The plates were shaken vigorously for 5 minutes. The absorbance was measured using microplate reader at a wavelength of $540 \mathrm{~nm}$. The percentage growth inhibition was calculated using formula;

$$
\% \text { cell inhibition }=100-\{(\mathrm{Ti}-\mathrm{Tz}) /(\mathrm{C}-\mathrm{Tz})\} \times 100
$$

Where, $\mathrm{Ti}=$ Absorbance value of test compound, $\mathrm{Tz}=$ Absorbance value of blank, $\mathrm{C}=$ Absorbance value of control.

\section{RESULT AND DISCUSSION}

\section{Material collection, identification and authentication}

Total five species of Chlorophytum i.e. borivilianum, tuberosum, laxum, comosum and arundinaceum were collected from different locations and identified as well as authenticated from Dr. Prabha Bhogonkar, Ex-HOD, Botany, Vidarbha Institute of Science and Humalities College, Amravati and Dr. Arvind S. Dhabe Professor, Department of Botany, Dr. Babasaheb Ambedkar Marathwada University, Aurangabad. Authenticated species further evaluated comparatively for their morphological, micro- 


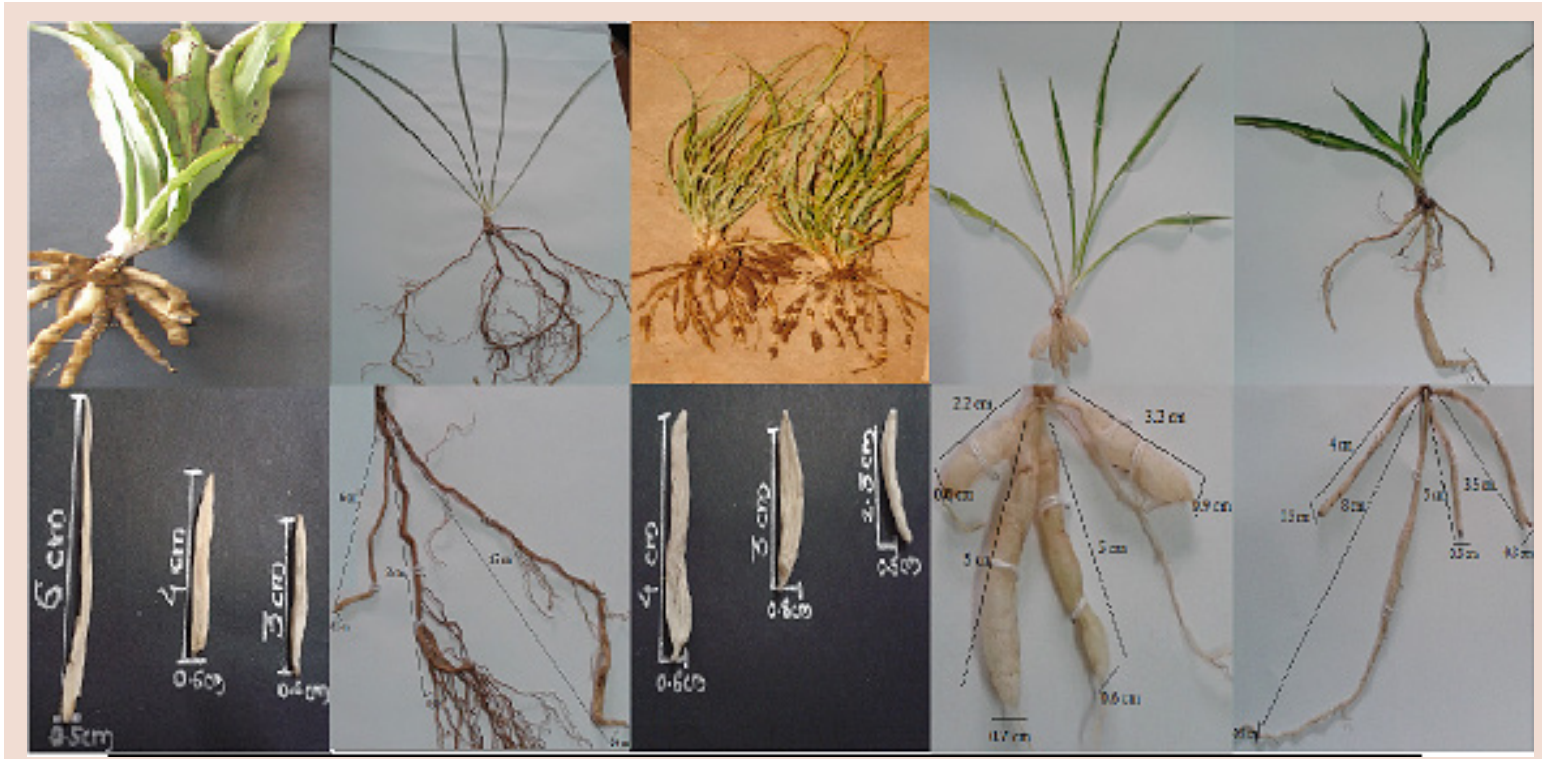

Figure 1: Comparative morphological evalaution between selected five Chlorophytum species

Table 1: Comparative morphological evaluation parameters of selected five Chlorophytum species

\begin{tabular}{|c|c|c|c|c|c|c|}
\hline & Features & CB & CC & $\mathrm{CT}$ & $\mathrm{CL}$ & CA \\
\hline \multirow{5}{*}{ Tubers } & Color & White to off white & White to cream & Off white to cream & White to off white & Off white to cream \\
\hline & Odour & Slight characteristics & $\begin{array}{c}\text { Slight characteristic } \\
\text { pleasant }\end{array}$ & Slight characteristic & Slight characteristic & Slight characteristic \\
\hline & Size & $\begin{array}{l}2 \text { to } 4 \mathrm{~cm} \text { in length } \\
\text { and } 0.5 \mathrm{~cm} \text { in width }\end{array}$ & $\begin{array}{c}10 \text { to } 15 \mathrm{~cm} \text { in length } \\
\text { and } 0.1-0.3 \mathrm{~cm} \text { in } \\
\text { width }\end{array}$ & $\begin{array}{c}3 \text { to } 7 \mathrm{~cm} \text { in length } \\
\text { and } 0.9 \text { to } 1.5 \mathrm{~cm} \text { in } \\
\text { width }\end{array}$ & $\begin{array}{l}0.9 \text { to } 2.5 \mathrm{~cm} \text { in } \\
\text { length and } 0.3 \text { to } 0.6 \\
\mathrm{~cm} \text { in width }\end{array}$ & $\begin{array}{c}3 \text { to } 8 \mathrm{~cm} \text { in length } \\
\text { and } 0.3 \text { to } 0.6 \mathrm{~cm} \text { in } \\
\text { width }\end{array}$ \\
\hline & Shape & $\begin{array}{c}\text { Elongated, hard, } \\
\text { tapering at both } \\
\text { the ends, fracture is } \\
\text { short }\end{array}$ & $\begin{array}{l}\text { Elongated, hard, } \\
\text { tapering towards } \\
\text { bottom, fracture is } \\
\text { short }\end{array}$ & $\begin{array}{l}\text { Elongated, thick } \\
\text { fleshy and tuber like, } \\
\text { hard, tapering at } \\
\text { both ends and short } \\
\text { fracture }\end{array}$ & $\begin{array}{c}\text { Elongated, hard, } \\
\text { tapering at bottom } \\
\text { with branching tread } \\
\text { like structure, short } \\
\text { fracture }\end{array}$ & $\begin{array}{c}\text { Elongated, hard, } \\
\text { tapering at both } \\
\text { the ends, fracture is } \\
\text { short }\end{array}$ \\
\hline & No. of roots & $8-10$ & $10-15$ & $15-20$ & $14-16$ & $8-10$ \\
\hline \multirow{4}{*}{ Leaf } & Length & $25 \pm 1.5 \mathrm{~cm}$ & $20 \pm 5.0 \mathrm{~cm}$ & $22 \pm 5.0 \mathrm{~cm}$ & $10 \pm 5 \mathrm{~cm}$ & $12 \pm 4 \mathrm{~cm}$ \\
\hline & Width & $1.0 \pm 1.5 \mathrm{~cm}$ & $1.0 \pm 0.5 \mathrm{~cm}$ & $10 \pm 5 \mathrm{~cm}$ & $0.4 \pm 0.2 \mathrm{~cm}$ & $0.4 \pm 0.2 \mathrm{~cm}$ \\
\hline & Color & Green colored & Green colored & Green colored & $\begin{array}{l}\text { Light green colored } \\
\text { with white margin at } \\
\text { the edges }\end{array}$ & $\begin{array}{l}\text { White colored } \\
\text { midrib with green } \\
\text { edges }\end{array}$ \\
\hline & No. of leaves & $5-12$ & $5-12$ & $5-10$ & $6-10$ & $5-12$ \\
\hline Stem & - & $\begin{array}{l}\text { Reduced with root } \\
\text { stock }\end{array}$ & $\begin{array}{l}\text { Reduced with root } \\
\text { Stock }\end{array}$ & $\begin{array}{l}\text { Reduced with root } \\
\text { Stock }\end{array}$ & $\begin{array}{l}\text { Reduced with root } \\
\text { Stock }\end{array}$ & $\begin{array}{l}\text { Reduced with root } \\
\text { Stock }\end{array}$ \\
\hline Flowers & - & $\begin{array}{l}\text { White, arranged in } \\
\text { alternate clusters } \\
\text { bracts liner papery } \\
\text { and purplish }\end{array}$ & $\begin{array}{c}\text { Small single white } \\
\text { with white petals } \\
\text { in an alternating } \\
\text { pattern }\end{array}$ & $\begin{array}{l}\text { White, with Elliptic } \\
\text { petals and erect } \\
\text { stamens with yellow } \\
\text { anthers. }\end{array}$ & $\begin{array}{l}\text { Small paired white } \\
\text { with greenish white } \\
\text { petals }\end{array}$ & $\begin{array}{l}\text { Small paired white } \\
\text { with greenish white } \\
\text { petals }\end{array}$ \\
\hline Seeds & - & $\begin{array}{l}\text { Black in colour, } \\
\text { orbicular. }\end{array}$ & $\begin{array}{l}\text { Flattish, black in } \\
\text { color and shiny. }\end{array}$ & $\begin{array}{l}\text { Lack in color with } \\
\text { angular edges. }\end{array}$ & $\begin{array}{l}\text { Black in colour with } \\
\text { oval shaped }\end{array}$ & $\begin{array}{c}\text { Black in colour with } \\
\text { oval shaped }\end{array}$ \\
\hline
\end{tabular}

scopical, physicochemical and phytochemical parameters and also evaluated for their antioxidant and anticancer potential by in-vitro methods.

Pharmacognostic evaluation, Macroscopic and Microscopic evaluation

Macroscopy of whole plant of all five species of Chlorophytum was studied and summarised in Figure 1 and Table 1. Powder microscopy of tubers of all species of Chlorophytum was studied in detailed. It was examined under microscope first with low power (10X) and then magnified with $45 \mathrm{X}$. (Figure 2) Microscopical examination of C. borivilianum shows fragments of lignified reticulate vessels, fibres with thin heavily lignified, pointed or bifurcated ends, thin walled elongated large packed parenchymatous cells, and thin walled colorless cork cells. Microscopical examination of $C$. comosum shows sclerenchymatous fibres, thin walled cork cells filled with few colorless and few are with yellowish brown matter, tracheids with thin walled, pitted lignified xylem vessels. Microscopi- 

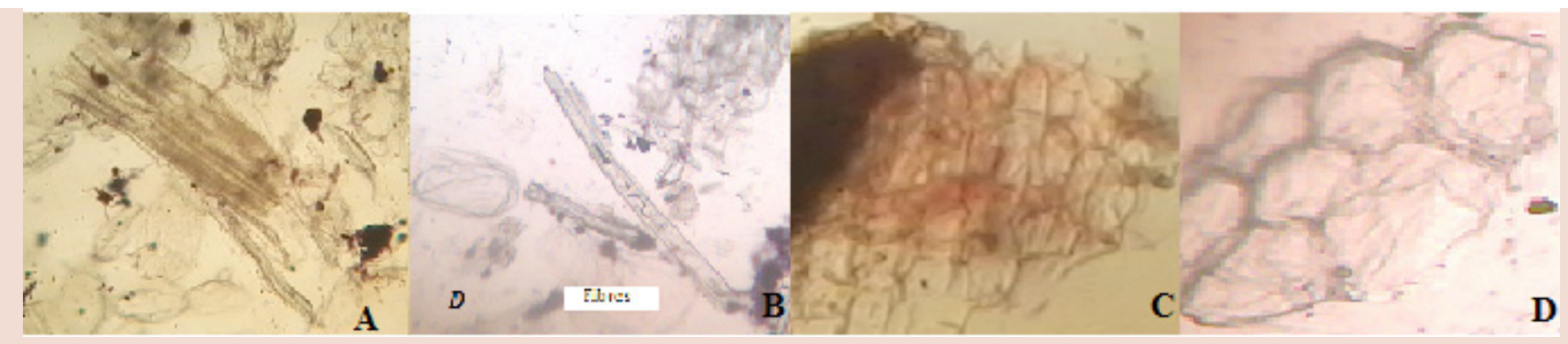

Chlorophytum borivilianum-A: Vessels-Fragments of lignified reticulate vessels; B: Fibre-Thick, heavily lignified with pointed or bifurcated ends; C: ParenchymaThin walled, elongated large cell, packed; D: Cork cells-Thin walled, colorless cork cells

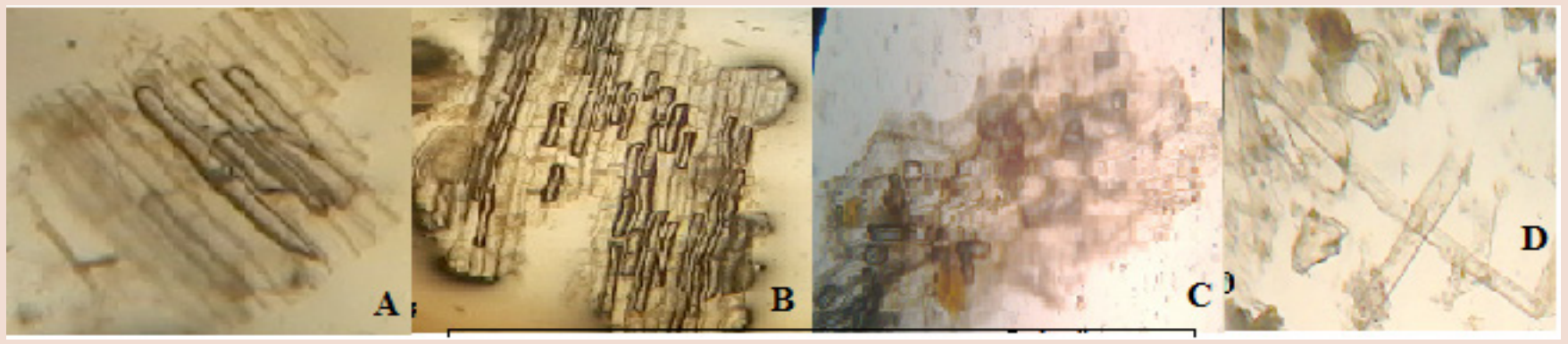

Chlorophytum comosum-A: Vessels; B: Xylem-Tracheids with thin walled, pitted lignified cells; C: Cork cells- Thin walled, few colorless and few are with yellowish brown matter; D: Fibre-Sclerenchymatous fibres
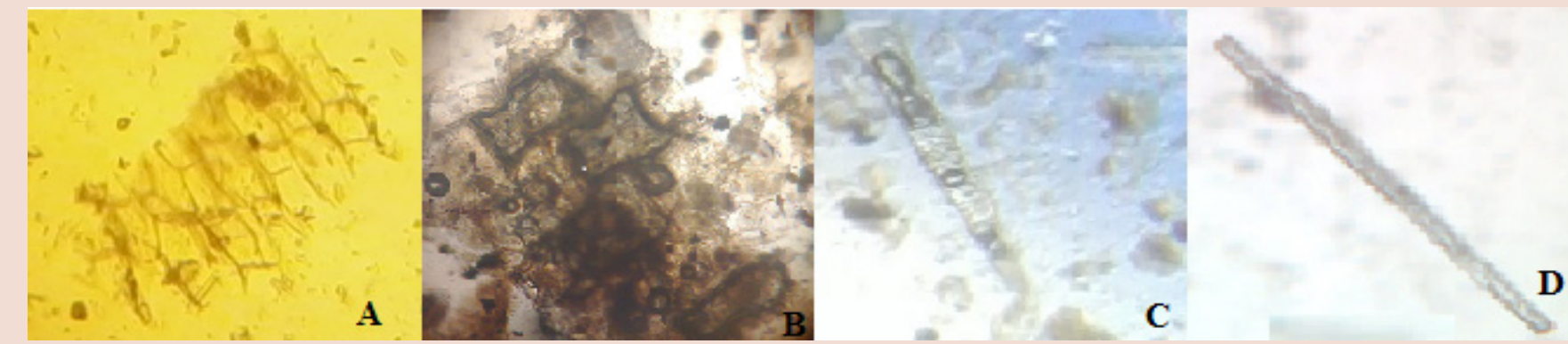

Chlorophytum tuberosum-A: Parenchyma- Lignified, pitted xylem parenchymatous cells, filled with some yellowish brown matter; B: Cork cells- Brownish thick walled, wavy cells containing brown matter (saponin, mucilage); C: Xylem vessels- Spiral tracheids with tapering end. D: Fibre Sclerenchymatous fibres

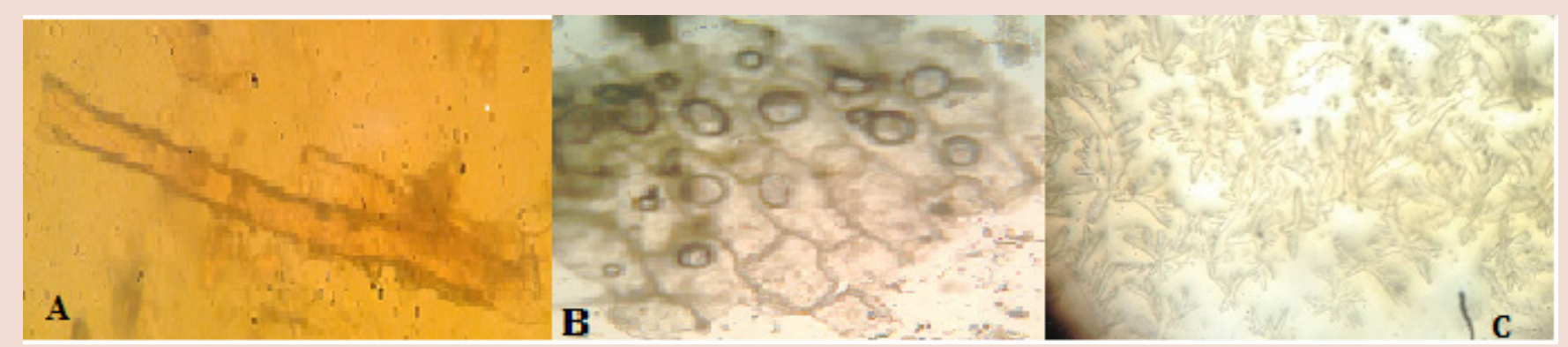

Chlorophytum Iaxum-A: Fibre- Sclerenchymatous fibres; C: Cork cells- Thin walled filled with brownish matter; C: Calcium oxalate crystals

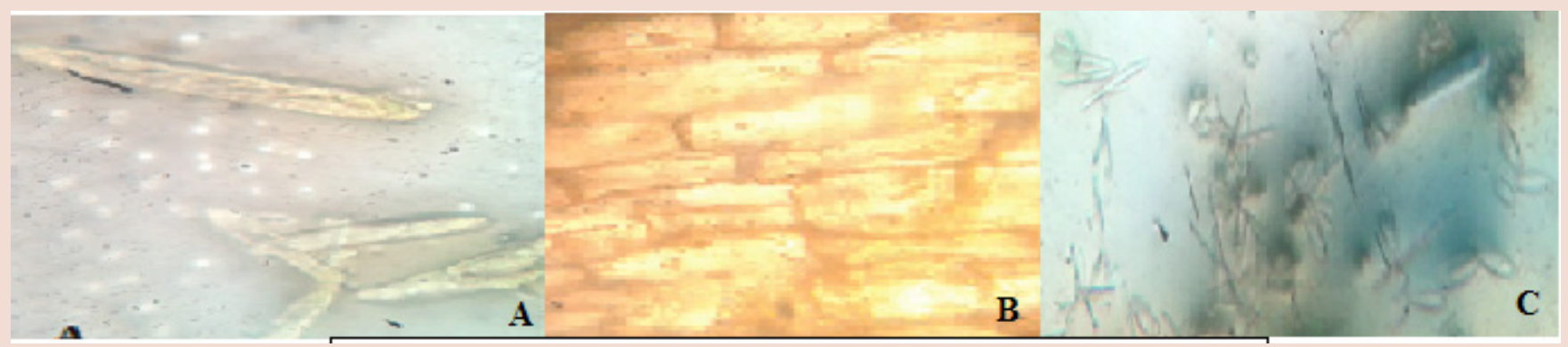

Chlorophytum arundinaceum-A: Fibres- Numerous, stratified thin walled lignified fibres; B: Cork cells -Thick walled, few colorless and few are with yellowish brown matter; C: Calcium oxalate crystals: Needle, oval shaped

Figure 2: Comparative powder microscopical evalaution between tubers of selected five Chlorophytum species 


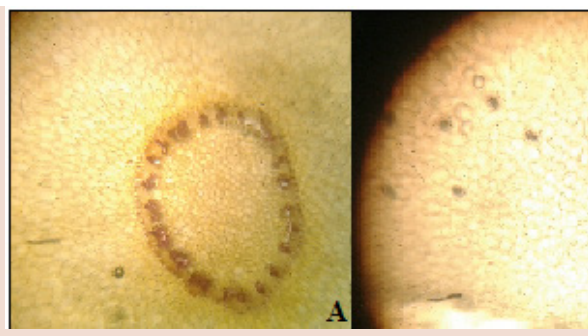

Transverse section of $C$. borivilianum

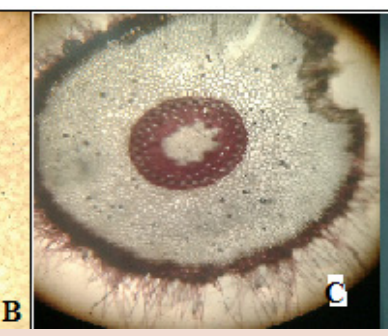

B

A: T. S. of C. borivilianum root showing presence of pith i. e. parenchymatous cells, endodermis; B: cortex region showing polygonal cells, cork cells which are present at outer layer; C: T. S. of root C. comosum showing presence of pith, parenchymatous cells, endodermis; D: cork cells which are present at outer layer; E: covering trichomes

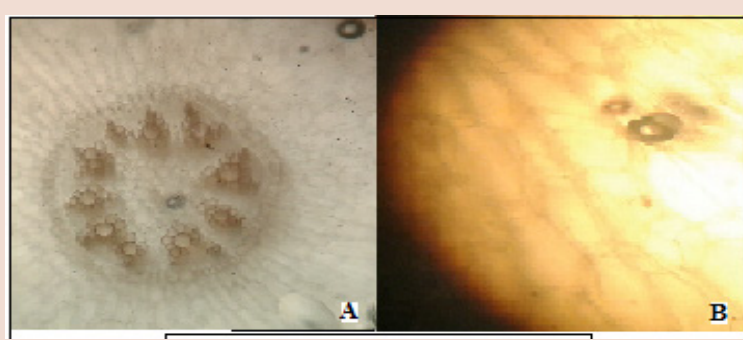

Transverse section of C. tuberosum

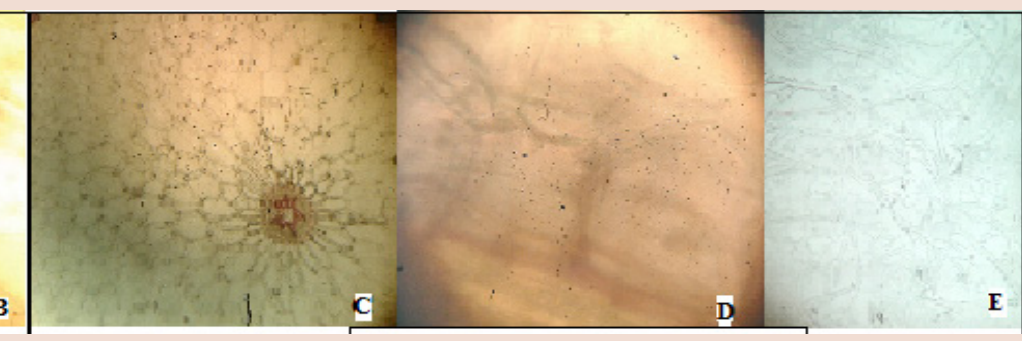

Transverse section of Chlorophytum laxum

A:T. S. of C. tuberosum root showing presence of pith, parenchymatous cells, endodermis; B: cork cells which are present at outer layer; C: T. S. of C. laxum root showing presence of pith, parenchymatous cells, endodermis; D: cork cells which are present at outer layer; E: Calcium oxalate crystals.

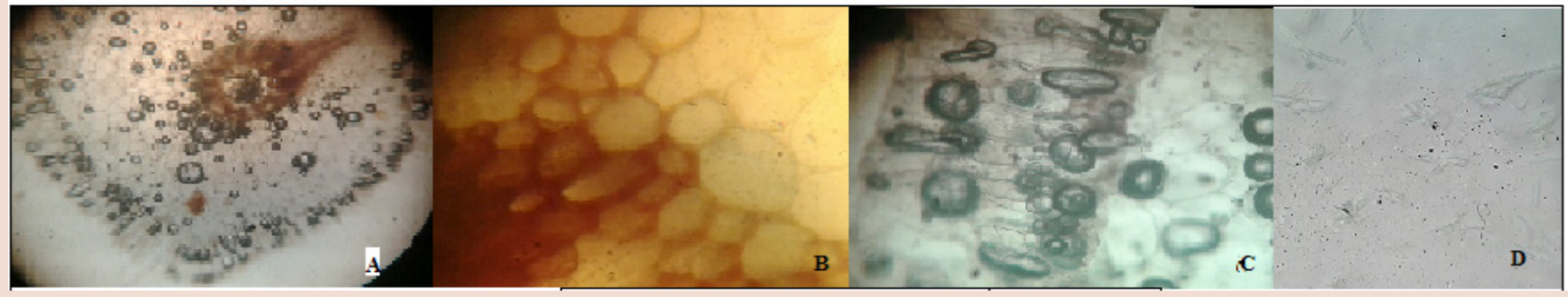

Transverse section of $C$. arundinaceum

A: T. S. of root showing presence of pith, parenchymatous cells, endodermis, cork cells; B: cortex region; C: cork cells which are present at outer layer; C: Calcium oxalate crystals; D: calcium oxalate crystals needle shaped.

Figure 3: Comparative histological evalaution between tubers of selected five Chlorophytum species

cal examination of C. tuberosum shows sclerenchymatous fibres, lignified, pitted xylem parenchymatous cells, brownish thick walled cork cells containing brown matter, spiral tracheids of xylem vessels with tapering ends. Microscopical examination of C. laxum shows sclerenchymatous fibre, thin walled cork cells filled with brownish matter, feather shaped calcium oxalate crystals. Microscopical examination of C. arundinaceum shows sclerenchymatous fiber, thick walled cork cells few colorless and few are with yellowish brown matter, some are needle and some are oval shaped calcium oxalate crystals. Transverse section of tubers (Figure 3 ) is observed under microscope first with low power i. e. $10 \mathrm{X}$ and then magnified with $45 \mathrm{X}$. On microscopical examination it shows presence of:

- Cortex: This is followed by a very large zone of cortex. The outermost layer of the cortex (which is outermost boundary in most pieces) just below the epidermis consist of cells which are of mostly rectangular, appearing much longer than wide. The rest of the cortical cells are rounded of polygonal, parenchymatous and have little or no intercellular spaces (probably due to swelling).

- Vascular bundle: The vascular tissue is not very elaborate. Xylem is consisting of joined vessels, 3-5in number in each group. There are about 30-35 groups of xylem. However fibres are quite abundant, surrounding the vessels are joined to form more or less continuous irregular ring. Phloems are arranged just above the xylem.
- Trichomes: An elongated outgrowth of an epidermal cell is termed as trichome or plant hair.

Physicochemical evaluation

Total ash includes both "physiological ash", which is derived from the plant tissue itself, and "non-physiological" ash, which is the residue of the extraneous matter adhering to the plant surface. Acid insoluble ash measures the amount of silica and siliceous earth. Water-soluble ash is the difference in weight between the total ash and the residue after treatment of the total ash with water. These values are useful for detecting low grade products, exhausted drug and excess of sandy or earthy matter. The LOD can help in deciding the percentage of moisture should be allowed in the dried crude drug which will not affect its shelf-life. Swelling index is determined to calculate the amount of mucilage present in drug. Foaming index is calculated to know the frothing property of drug. Total saponin content is determined for quantitative analysis of saponin. All determined physicochemical constants are given in Table 2 which can further used for standardisation of selected plants.

\section{Phytochemical evaluation}

Powder of C. borivilianum, C. comosum, C. tuberosum, C. laxum and Chlorophytum arundinaceum species extracted with ethanol and water. The aqueous and ethanolic extracts of collected species are tested for dif- 
Table 2: Physicochemical parameters for selected five Chlorophytum species

\begin{tabular}{|c|c|c|c|c|c|}
\hline Physical constants & CB & $\mathrm{CC}$ & CT & $\mathrm{CL}$ & CA \\
\hline Total ash value $[\% \mathrm{w} / \mathrm{w}]$ & 4.08 & 8.22 & 7.17 & 6.61 & 6.81 \\
\hline Acid insoluble ash $[\% \mathrm{w} / \mathrm{w}]$ & 0.15 & 0.91 & 0.66 & 0.45 & 0.59 \\
\hline Water soluble ash [\% w/w] & 0.61 & 1.89 & 1.16 & 0.90 & 0.92 \\
\hline Loss on drying $[\% \mathrm{w} / \mathrm{w}]$ & 20.1 & 21.9 & 27.5 & 16.1 & 10.8 \\
\hline Swelling index & 6.00 & 4.00 & 6.50 & 6.50 & 7.00 \\
\hline Foaming index & 250 & 333.33 & 333.33 & $>100$ & 142.82 \\
\hline Total saponin content & $4.5 \%$ & $6.5 \%$ & $6.0 \%$ & $1.0 \%$ & $1.5 \%$ \\
\hline
\end{tabular}

CB: Chlorophytum borivilianum, CC: Chlorophytum comosum, CT: Chlorophytum tuberosum, CL: Chlorophytum laxum, CA: Chlorophytum arundinaceum

Table 3: Preliminary Phytochemical Evaluation for selected five Chlorophytum species

\begin{tabular}{|c|c|c|c|c|c|c|c|c|c|c|}
\hline Test & & & & & & & & & & \\
\hline Species $\Longrightarrow$ & & & & & & & & & & \\
\hline 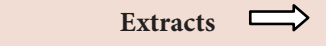 & $\mathrm{AE}$ & EE & $\mathbf{A E}$ & EE & $\mathrm{AE}$ & EE & $\mathbf{A E}$ & EE & $\mathbf{A E}$ & EE \\
\hline Phytochemical class & & & & & & & & & & \\
\hline Carbohydrates & +ve & +ve & +ve & +ve & +ve & $+\mathrm{ve}$ & +ve & $+\mathrm{ve}$ & +ve & $+\mathrm{ve}$ \\
\hline Proteins & -ve & -ve & -ve & -ve & -ve & -ve & -ve & -ve & -ve & -ve \\
\hline Alkaloids & -ve & +ve & -ve & -ve & -ve & -ve & + ve & +ve & +ve & +ve \\
\hline Cardiac Glycoside & -ve & -ve & -ve & -ve & -ve & -ve & -ve & -ve & -ve & -ve \\
\hline Anthraquinone Glycoside & -ve & -ve & -ve & -ve & -ve & -ve & -ve & -ve & -ve & -ve \\
\hline Cynogenetic Glycoside & -ve & -ve & -ve & -ve & -ve & -ve & -ve & -ve & -ve & -ve \\
\hline Coumarin Glycoside & -ve & -ve & -ve & -ve & -ve & -ve & -ve & -ve & -ve & -ve \\
\hline Saponin Glycoside & + ve & -ve & $+\mathrm{ve}$ & -ve & +ve & -ve & $+\mathrm{ve}$ & -ve & $+\mathrm{ve}$ & -ve \\
\hline Flavonoids & +ve & $+\mathrm{ve}$ & $+\mathrm{ve}$ & + ve & +ve & + ve & + ve & $+\mathrm{ve}$ & $+\mathrm{ve}$ & +ve \\
\hline Tannins & +ve & +ve & +ve & +ve & -ve & -ve & -ve & -ve & +ve & +ve \\
\hline Steroid or Triterpenoid & -ve & -ve & + ve & $+\mathrm{ve}$ & $+\mathrm{ve}$ & + ve & $+\mathrm{ve}$ & $+\mathrm{ve}$ & -ve & -ve \\
\hline Saponin & + ve & -ve & + ve & -ve & $+\mathrm{ve}$ & -ve & + ve & -ve & $+\mathrm{ve}$ & -ve \\
\hline For Powder Drug & & & & & & & & & & \\
\hline Gum & -ve & - & -ve & - & -ve & - & -ve & - & -ve & - \\
\hline Mucilage & +ve & - & +ve & - & +ve & - & $+\mathrm{ve}$ & - & +ve & - \\
\hline Fatty Oil & -ve & - & -ve & - & -ve & - & -ve & - & -ve & - \\
\hline Essential Oil & -ve & - & -ve & - & -ve & - & -ve & - & -ve & - \\
\hline
\end{tabular}

CB: Chlorophytum borivilianum, CC: Chlorophytum comosum, CT: Chlorophytum tuberosum, CL: Chlorophytum laxum, CA: Chlorophytum arundinaceum, AE: Aqueous extract, EE: Ethanolic extract. +ve: Present, -ve: Absent.

ferent phytoconstituents like carbohydrates, proteins, alkaloids, glycosides, saponins, tannins, terpenoids, flavonoids, protein, mucilages and volatile oils. (Table 3) The Knowledge of the chemical constituents of plants is desirable because such information will be valuable for synthesis of complex chemical substances and to screen for biological activities. A preliminary phytochemical evaluation of $C$. borivilianum reveals presence of carbohydrates, alkaloids, saponin, flavonoid, tannin, saponin glycosides and mucilages. A preliminary phytochemical evaluation result of C. comosum reveals presence of carbohydrates, saponin, flavonoid, steroids or triterpenoid, saponin glycosides and mucilages. A preliminary phytochemical evaluation result of C. tuberosum reveals presence of carbohydrates, alkaloids, saponin, flavonoid, steroids or triterpenoid, saponin glycosides and mucilages. A preliminary phytochemical evaluation result of C. laxum reveals presence of carbohydrates, alkaloids, saponin, flavonoid, tannin, saponin glycosides and mucilages. A preliminary phy- tochemical evaluation result of Chlorophytum arundinaceum species reveals presence of carbohydrates, alkaloids, saponin, flavonoid, tannin, saponin glycosides and mucilages. C. comosum contain large amount of alkaloids, saponins as compared to other 4 species. The saponins, phenolic and flavonoids are widely distributed secondary metabolites in plants having anti-oxidant activity and wide range of biological activities as anti-apoptosis, anti-aging, anti-carcinogen, anti-inflammatory, cardiovascular protection and improvement of endothelial function, as well as inhibition of angiogenesis and cell proliferation activities.

\section{Chromatographic Studies}

In Thin Layer Chromatographic (TLC) studies, it is observed that maximum saponins are separated in mobile phase A. Maximum numbers of saponins (6) are observed in tuberosum species. On the basis of RF (Retention factor) values, few saponin bands are same in all species ex- 
Table 4: Details of TLC evaluation of all Chlorophytum species

\begin{tabular}{|c|c|c|c|c|}
\hline \multirow[b]{2}{*}{ Species } & \multicolumn{2}{|c|}{$\begin{array}{c}\text { Mobile Phase A Chloroform: Methanol: Glacial acetic } \\
\text { acid: water (6.5:3.2:1.2:0.8) }\end{array}$} & \multicolumn{2}{|c|}{ Mobile Phase B Chloroform: methanol: water (7.0:3.0:0.4) } \\
\hline & Total Spot & Spot details & Total Spot & Spot details \\
\hline C. borivilianum & 4 & $\begin{array}{l}\text { Light brown } 0.191 \text {, Light brown } 0.375 \text {, } \\
\text { Light brown } 0.559 \text {, Yellow } 0.632 \text {. }\end{array}$ & 2 & $\begin{array}{ll}\text { Light brown } & 0.100 \\
\text { Light brown } & 0.319\end{array}$ \\
\hline C. comosum & 3 & $\begin{array}{l}\text { Light brown } 0.194 \text {, Light brown } 0.353 \text {, } \\
\text { Light brown } 0.568\end{array}$ & 2 & $\begin{array}{ll}\text { Light brown } & 0.100 \\
\text { Light brown } & 0.319\end{array}$ \\
\hline C. tuberosum & 6 & $\begin{array}{l}\text { Light brown } 0.180 \text {, Light brown } 0.360 \text {, } \\
\text { Yellow } 0.461 \text {, Light brown 0561, Yellow } \\
0.626 \text {, Yellow } 0.763\end{array}$ & 2 & $\begin{array}{ll}\text { Light brown } & 0.100 \\
\text { Light brown } & 0.308\end{array}$ \\
\hline C. laxum & 4 & $\begin{array}{l}\text { Light brown } 0.201 \text {, Light brown } 0.360 \text {, } \\
\text { Light brown } 0.561 \text {, Yellow } 0.691\end{array}$ & 2 & $\begin{array}{ll}\text { Light brown } & 0.100 \\
\text { Light brown } & 0.310\end{array}$ \\
\hline C. arundinaceum & 4 & $\begin{array}{l}\text { Light brown } 0.209 \text {, Light brown } 0.216 \text {, } \\
\text { Light brown } 0.554 \text {, Yellow } 0.763\end{array}$ & 2 & $\begin{array}{cc}\text { Yellow } & 0.100 \\
\text { Light brown } & 0.310\end{array}$ \\
\hline
\end{tabular}

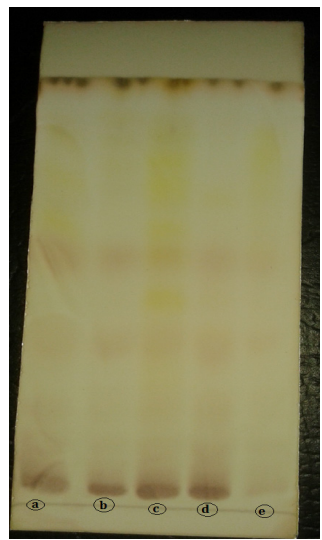

TLC plate of Mobile Phase-A

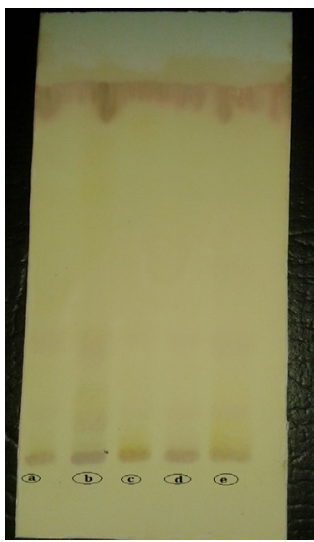

TLC plate of Mobile Phase-B

a: Spot of methanolic extract of C. borivilianum, b: Spot of methanolic extract of C. comosum, c: Spot of methanolic extract of C. tuberosum, d: Spot of methanolic extract of C. laxum, e: Spot of methanolic extract of C. arundinaceum plant.

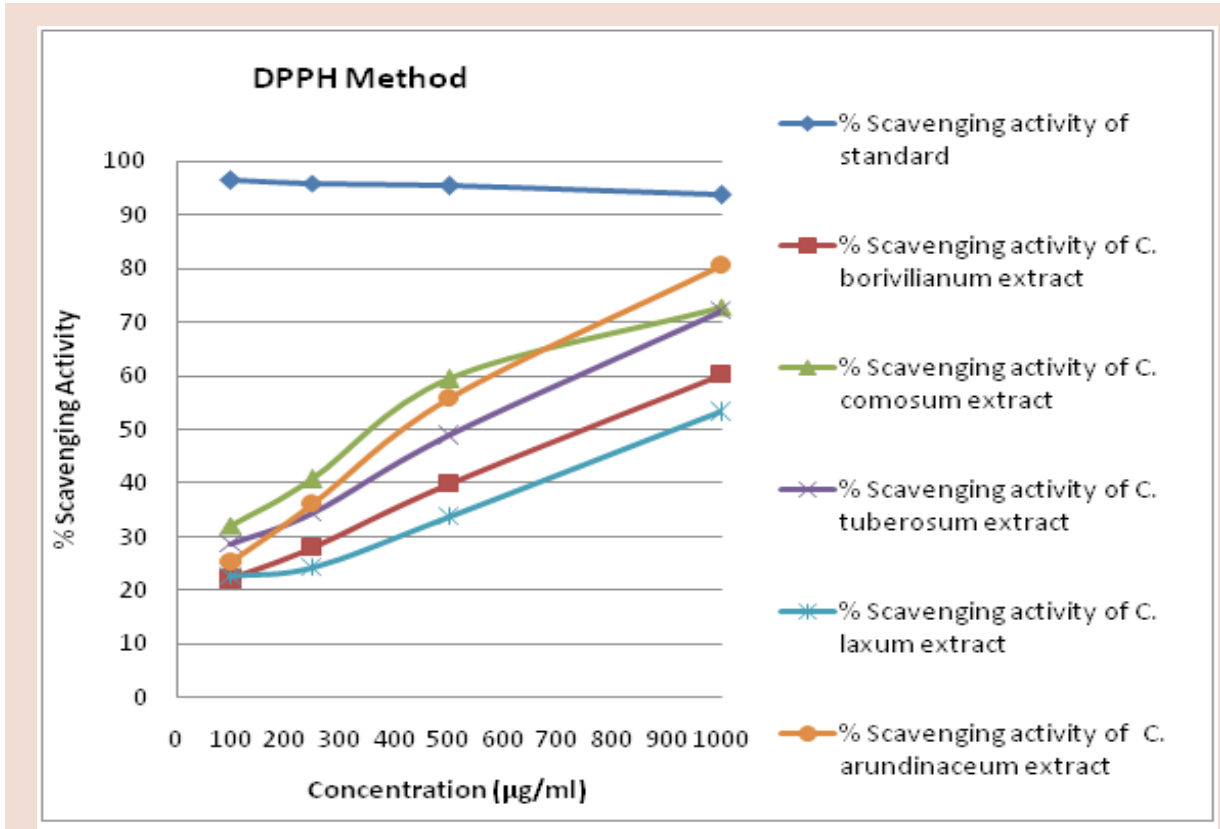

Figure 4: Percentage scavenging activity of selected five species of Chlorophytum species 
cept tuberosum and arundinaceum species where extra bands are also observed at different RF values. (Table 4) It is observed that maximum sapnins are separated in mobile phase A. Maximum number of saponins (6) are observed in tuberosum species. Same saponin pattern is observed for few saponins in all species except tuberosum and arundinaceum species.

\section{In-vitro Antioxidant Activity}

In-vitro antioxidant activity of methanolic extract of C. borivilianum, $C$. comosum, C. tuberosum, C. laxum and C. arundinaceum species was performed by DPPH scavenging radical activity. Result demonstrates that all plant extract have antioxidant activity. (Figure 4) Among all species, C. arundinaceum shown strong antioxidant activity, while C. comosum and C. tuberosum shown significant activity, C. borivilianum shown moderate activity and C. laxum shown weak activity.

In-vitro anticancer screening by SRB assay method

Saponins belong to a group of naturally derived compounds, which have demonstrated substantial cytotoxic activity through different mechanisms. With this background we decided to evaluate probable anticancer effect of saponins of Chlorophytum species on leukemia cell lines. Invitro anticancer activity of methanolic extract and saponin fraction of C. borivilianum, C. comosum, C. tuberosum, C. laxum and unidentified Chlorophytum species was studied by SRB assay method on HL60 leukemia cell line. Result demonstrates (Table 5) that C. comosum methanolic extract inhibited the growth of HL 60 cells to certain extent but not potent in effect. It is also found that remaining species extracts and fractions do not possess anticancer effect against leukemia cell line, but may act as anticancer agent against other types of cancer. Hence future scope involves screening Saponins of Chlorophytum species on different

Table 5: In-vitro anticancer activity results by SRB method

\begin{tabular}{cccc}
\hline Cell line & \multicolumn{3}{c}{ Drug concentration $(\mu \mathrm{g} / \mathrm{ml})$ calculated from graph } \\
\hline HL 60 & LC50 & TGI & GI150 \\
Test 1 & $>80$ & $>80$ & $>80$ \\
Test 2 & $>80$ & $>80$ & 57.2 \\
Test 3 & $>80$ & $>80$ & $>80$ \\
Test 4 & $>80$ & $>80$ & $>80$ \\
Test 5 & $>80$ & $>80$ & $>80$ \\
Test 6 & $>80$ & $>80$ & $>80$ \\
Test 7 & $>80$ & $>80$ & $>80$ \\
Test 8 & $>80$ & $>80$ & $>80$ \\
Test 9 & $>80$ & $>80$ & $>80$ \\
Test $\mathbf{1 0}$ & $>80$ & $>80$ & $>80$ \\
ADR & $>80$ & 32.0 & $<10$ \\
\hline
\end{tabular}

Where Test 1: C. borivilianum extract, Test 2: C. comosum extract, Test 3: $C$. tuberosum extract, Test 4: C. laxum extract, Test 5: C. arundinaceum extract, Test 6: C. borivilianum saponin fraction, Test 7: C. comosum saponin fraction, Test 8: C. tuberosum saponin fraction, Test 9: C. laxum saponin fraction, Test 10: C. arundinaceum saponin fraction and ADR: Adriamycin (Doxorubicin). Known drug GI50 : Growth inhibition of 50 \% (GI50) calculated from [(Ti-Tz)/ $(\mathrm{C}-\mathrm{Tz})] \times 100=50$, drug concentration resulting in a $50 \%$ reduction in the net protein increase TGI: Drug concentration resulting in total growth inhibition (TGI) will calculated from $\mathrm{Ti}=\mathrm{Tz}$ LC50 : Concentration of drug resulting in a $50 \%$ reduction in the measured protein at the end of the drug treatment as compared to that at the beginning) indicating a net loss of $50 \%$ cells following treatment is calculated from $[(\mathrm{Ti}-\mathrm{Tz}) / \mathrm{Tz}] \times 100=-50$. cancer cell lines.

\section{CONCLUSION}

In conclusion all collected species extract have antioxidant activity may be due to presence of saponin, tannins or flavonoids. Unknown Chlorophytum species plant is more efficient antioxidant agent as compared to other collected (four) species while C. comosum and C. tuberosum significant antioxidant activity and C. borivilianum and C. laxum give moderate antioxidant activity. While methanolic extract and saponin fraction of C. borivilianum, C. comosum, C. tuberosum, C. laxum and C. arundinaceum do not possess in-vitro anticancer effects against $\mathrm{HL}$ 60 leukemia cell line, but may act as anticancer against other types of cancer due to presence of saponins, flavonoids and alkaloids. Finally it can be concluded that all five species have morphological, microscopical, chemical differences and even same for antioxidant activity. But all species do not found anticancer against HL-60 except $C$. comosum which have $\mathrm{IC}_{50}$ is $57.2 \%$ and other above $80 \%$.

\section{ACKNOWLEDGMENTS}

Authors are thankful to Advanced Center for Treatment, Research and Education in Cancer (ACTREC), Mumbai for evaluating anticancer potential of extracts and Dr. Prabha Bhogonkar, Ex-HOD, Botany, Vidarbha Institute of Science and Humalities College, Amravati and Dr. Arvind S. Dhabe Professor, Department of Botany, Dr. Babasaheb Ambedkar Marathwada University, Aurangabad for helping in authentication of plant species.

\section{REFERENCES}

1. Devendra Singh, Bhagirath Polchriyal, Joshi YM, Vilasrao Kadam. Phytophar macological aspect of Chlorophytum borivilianum (Safed mus/l): A review. International journal of research in pharmacy and chemistry. 2012; 2(3): 8539.

2. Manish Kumar, Priyadarshi Meena, Shekhar Verma, Madhu Kumar, Ashok Kumar. Anti-tumour, anti-mutagenic and chemomodulatory potential of Chlorophytum borivilianum. Asian pacific journal of cancer prevention. 2010; 11(1): 327-34.

3. Kunal Kale, Prashant Thakre. Genus Chlorophytum Ker Gawl: Medicinally important plant from ancient Indian literature (Ayurveda). International journal of ayurvedic and herbal medicine. 2013; 3(3): 2249-5746.

4. Kaushik N. Saponins of Chlorophytum species, Phytochemistry Reviews. 2005; 4(3): 191- 6

5. Marais W. Reilly J. Chlorophytum and Its Related Genera (Liliaceae). Kew Bulletin. 1978; 32(3): 653-63.

6. Kothari SK. Safed Moosli (Chlorphytum borivilianum) revisited. Journal of Medicinal and Aromatic Plant Sciences. 2004; 26(1): 60-3.

7. Yoshihiro Mimaki, Toshihiro Kanmoto, Yutaka Sashida, Atsuko Nishino, Yoshiko Satomi, Hoyoku Nishino. Steroidal saponins from the underground parts of Chlorophytum comosum and their inhibitory activity on tumour promoter-induced phospholipids metabolism of hela cells. Phytochemistry. 1996; 41(5): 1405-10.

8. Patil VN, Deokate SS. Pharmacognostic study of Chlorophytum tuberosum baker. International journal of Ayurveda research. 2011; 1(4): 237-42.

9. Sreevidya Narasimhan, Raghavan Govindarajan, Madhavan Vijayakumar, Shanta Mehrotra. Free radical scavenging potential of Chlorophytum tuberosum Baker. Journal of Ethnopharmacology 2006; 104(3): 423-5.

10. Khandelwal KR. edited by Vrunda K Sethi; Practical Pharmacognosy, $20^{\text {th }}$ edition- Nirali prakashan Pune; 2010.

11. Evans W C; Trease and Evans Pharmacognosy, $15^{\text {th }}$ editionHarcourt publishers limited; 2002. 22, 24, 53, 289-304, 298, 65.

12. Rangari VD. Pharmacognosy and Phytochemistry- volume $2,2^{\text {nd }}$ editionCareer publication; 2009. 33, 122, 148, 160, 170, 206, 208, 220, 248.

13. Wagner H, Bladt S. Plant drug analysis. A thin layer chromatography atlas, second edition; Springer Publication; 1996. 306.

14. Sucheta Gaikwad A, Gayatri Kamble S, Swati Devare, Nirmala Deshpande R, Jyoti Salvekar p. In-vitro evaluation of free radical scavenging potential of Cassia auriculata L. Journal of chemistry and pharmaceutical research 2011 ; 3(4): 766-72. 


\section{ABOUT AUTHOR}

Dr. S. L Deore: Is GOLD MEDALIST in B.PHARM from North Maharashtra University in 2004. She has completed M.Pharm from Govt. College of pharmacy, Amravati in 2006. She has awarded PhD in pharmaceutical sciences by SGB Amravati University in May 2011. She has isolated two saponins in her PhD work. She has authored two books "Plant biosynthesis" and "Experimental Phytopharmacognsoy" for Nirali Prakashan, Pune. Recently she has published Textbook of Pharmacognosy by PharmMed Press, Hyderabad. Her areas of research are isolation and structural elucidation of phytochemicals, neutraceutical development, and traditional medicine screening, chromatographic and phytochemical analysis of extracts. 